\title{
Drawn Commuters Caricature as a visual historical resource
}

\author{
ZSÓFIA KISŐRSI
}

\begin{abstract}
Despite of the fact that during the time of state socialism commuters meant a continuously growing social group both in proportion and in size, writing about their social history has been pushed into the background so far. The author's aim is to fill this gap by trying to discover the most of the available sources of different genres. The present study shows part of this larger volume work, it shows what it can add to our knowledge about a social group through traditional sources if we include caricatures of a given social group as visual historical sources in the analysis.

In this paper, the author analyses sixteen caricatures of commuters, published in "Ludas Matyi," comparing written and audio visual sources. In the study, she tries, among other things, to find out if there was a definite commuter picture of "Ludas Matyi", and if so, to what extent did this commuter's image differ from that of other products in the press? To what extent did the satirical portrayal of commuters refer to long-distance commuters and to what extent to daily commuters? Were the real anomalies of commuting in the era reflected in Ludas Matyi?

The analysis discusses the economic and social processes that characterize the time of publishing the caricatures, and denominates the external and internal characteristics and emotions commuters were endowed with.The aim of the author is to present the method of caricature analysis, which emphasizes the comparability of resources.
\end{abstract}

KEYWORDS: commuters, state socialism, emotions, caricatures, visual historical resource

\section{ABSZTRAKT}

\section{Átrajzolt ingázók}

Karikatúra mint vizuális történeti forrás

Annak ellenére, hogy az államszocialista időszakban jelentős, arányaiban és nagyságában is folyamatosan növekvő társadalmi csoportot jelentettek az ingázók, társadalomtörténetük megírása mindezidáig háttérbe szorult. A szerző célja ennek a hiánynak a pótlása, úgy, hogy megpróbálja feltárni az elérhető legtöbb, különböző müfajú forrást. A jelen tanulmány ennek a nagyobb volumenú munkának egy részét mutatja be, azt, hogy mit tehet hozzá egy társadalmi csoportról hagyományos források útján szerzett ismereteinkhez, hogyha az adott társadalmi csoportról készült karikatúrákat mint vizuális történeti forrásokat is bevonjuk az elemzésbe. 


\section{THEMATIC PAPERS - Worker - life - representation}

A szerző a jelen tanulmányban tizenhat Ludas Matyiban megjelent, ingázókat ábrázoló karikatúrát írott és audiovizuális forrásokkal összehasonlítva elemez. A tanulmányban többek között igyekszik megválaszolni, hogy volt-e a Ludas Matyinak egy meghatározható ingázó képe, s ha igen, akkor ez az ingázó kép mennyiben tért el a sajtó más produktumainak ingázó képétől? A szatirikus lap ingázó ábrázolása mennyiben vonatkozott a távolsági ingázókra és mennyiben a napi ingázókra? Tükröződtek a korszak ingázó-létének tényleges visszásságai a Ludas Matyiban? Az elemzés kitér a karikatúrák publikálásának idejét jellemző gazdasági és társadalmi folyamatok ismertetésére, és az ingázókra felruházott külső és belsô tulajdonságok, érzelmek megnevezésére. A szerző célja egy olyan karikatúra elemzési módszer bemutatása, amely a források összehasonlíthatóságát helyezi előtérbe.

KULCSSZAVAK: ingázók, államszocializmus, érzelmek, karikatúrák, Ludas Matyi, vizuális történeti forrás

\section{Introduction}

"Ludas Matyi" distributed its caricatures for almost fifty years nationwide; the caricatures many times criticized the society and often mediated a higher political will. Despite the fact, that the profile of "Ludas Matyi" went through several changes as well - as adapted to the particular political influence-, still, it can be said that the weekly represented constancy during the time of the regime changes between 1945 and 1992. Taking this into consideration it is not surprising that no one has overtaken the tremendous task, best suited to teamwork, to make a comprehensive, detailed analysis of the caricatures of "Ludas Matyi." However, more historians of social history have extended their analysis to the thematically selected "Ludas" caricatures related to their research topic. The author of the present study did the same when collected and systematized the caricatures related to commuting.

In the present study whileanalysing the caricatures from question to question I will attempt to summarize the things that are known about the commuters of the socialist period.According to my hypothesis, as the drawers, editors and most of the subscribers of "Ludas" lived in Budapest, they met most of non-urban workers in the near and around the railway stations. That is the reason why they wanted to depict long distance commuters in their drawings, among whom - as opposed to the daily commuters - women were significant.

Were caricatures focusing on commuters as individuals only or on families including a commuter, as well? What was age - sex - commuting type (daily or long-distance commuting) breakdown of the caricaturists' commuters? How was the space used in the caricatures? What external (clothing, hairstyle, physique) and internal traits were given to the commuters?

In the summary, I will try to answer to the questions whether there were as many commuter images as artists or there were common features as well. And if the answer is yes, if there was a defined image that was used in "Ludas Matyi" then how 


\section{THEMATIC PAPERS - Worker - life - representation}

different this picture was from the other commuting pictures of the media. To what extend was the depiction of the commuters related to the long-distance commuters, to the so-called "black trains" society, and to what extend was it related to the daily commuters in the satirical weekly? Finally, I would like to find out how well real discrepancies of commuting are reflected in "Luda Matyi" during the period.

\section{Resources and methodology}

I have been studying and examining commuters of the state socialist period for years. After collecting information and knowledge from various written resources I became more and more interested in the visual and audio visual resources. I was not interested in the genre or the artists but rather in the extra information that was not given by the written resources, the information that can upgrade my impression about commuters. In the present study, similarly to Tibor Kaján quoted in the following lines, I look at caricatures as an emblem of the era: „The real caricature (that grows in good weather conditions and if taken real care of) can depict the emblem of the day, the week or the era; sometimes summarizing and concentrating on all the things that are detailed on the other pages of the magazines or papers. Therefore, it is a mistake to regard to caricatures as being single-celled creatures or entertaining knick-knacks that should be placed somewhere between the crosswords and the fishing column - if there is room, if there is a gap on the page perchance." (Kaján 1982: 97)

Unfortunately the analysis does not point out the artistic diversity of the caricatures, it does not analyse the professional life of the artists deliberately, and the detailed presentation/demonstration of the platforms of caricatures, in this case "Ludas Matyi", remains in the background as well. Instead, the analysis meticulously examines the caricatures, having the same questions asked at every illustration to get a wider knowledge about the topic thereby, by either gaining new information or by enforcing the previously acquired knowledge to be sounder.

Themethodology of the presentanalysisisnotbased onan existingwell-established method, but on combining different methods of historical worksthat are motivating for the author. I refer caricatures as a visual resource that had similar function as other forms of media - films, photos, articles- during the state socialist period. I will analyze the caricatures regarding the following theoretical considerations: 1) I consider it important to disclose the economic and societal processes characterizing the time of the publication of cartoons, 2) I will deliberately ignore the well-known periodization phases, 3) I will focus on the close reading of caricatures, 4) I will try to determine the complex system of references by identifying the emotions as well that are given to the commuters 5) deliberately I do not apply the requirements of the well-known caricatures or the content analysis literature, as during my analysis I 


\section{THEMATIC PAPERS - Worker - life - representation}

consider it the most important to analyse the resources so the information obtained from them could easily be compared with information of other sources. 6) After several attempts with different models for the denomination and classification of the emotions commuters were endowed with I will apply the catalysis model in my study, as the system of this model can be applied the best in the case of caricatures. As it is set in the official definition: "the catalysis model is a motivational theory assuming 7 basic needs. Along the 7 sets of needs in the model, emotions can be divided into $2 \times 7$ groups: seven positive and seven negative emotions. If a need is satisfied, then the positive emotions are manifested, but if it is not satisfied, then they are negative."In the present study I will only focus on the seven negative emotions: fear, boredom, anger, sadness, confusion, fatigue, and emptiness, as the main characters of the caricatures, the commuters were depicted exclusively with negative emotions by the creators.

Ludas Matyi, which was distributed from 1945, became the third most popular paper after "Népszabadság" and TV magazine ("Tévéújság") in the domestic market with its 600000 circulation in the first half of the Kádár-era (Takács 2006). The magazine was not published during the revolution of 1956; it was restarted in February 1957 with new editors and under a new management. The new wave is shown by the roundtable discussion of "Népszabadság" on Hungarian humour. On this occasion György Mikes stated that „humour has significantly big value for the society, and so does political humour for the politics. Humour is extremely suitable for the useful truths to be said; an extremely good humour however will not bring up bad feelings."(Anonymus 1971: 5)

The first analysis of this early period of "Ludas Matyi" was published in 1986 first, written by Zsuzsa Demeter. She perceived well that "the number of illustrations specifically about political events significantly decreases between 1957 and 1968 and in the same time, the number of caricatures showing and judging the direct environment and everyday life increases. (...) The conflict between Budapest and the village is a constant issue." (Demeter 1986: 19) The author's reflections are consistent with Demeter's statement. On the other hand, however, the author of the present lines solely observed the caricatures on commuting, and refrains from the general evaluation of the satire policy of "Ludas Matyi."

In the (digitalized) editions of "Ludas Matyi" were published for 47 years between 1945 and 1992 I have found 22 commuting caricatures from minimum 16 but probably more creators after searching for the keywords commuter, commuting, daily-traveller, „kétlaki”, worker, peasant, peasant worker, workers' hostel, workers' train, passenger, railway, train, bus, waiting room, plant, collective farm, village, rural, alcohol, drinking, pub. Most of the creators made only one caricature respectively that the research focuses on, only György Brenner made three. Therefore, we cannot talk about caricaturists specializing portraying commuters. The time distribution of 


\section{THEMATIC PAPERS - Worker - life - representation}

the commuter caricatures is the following: up to 1956 eight commuter caricatures were published in total; I will not analyze these caricatures in this study. I will present the emotions to the commuters in the sixteen caricatures that were published after 1956, between 1960 and 1985 .

\section{How were they seen as?}

The first question to be answered is who the focus group was; was it the commuting individual who was in the focal point of the caricatures or was it the commuter's family? The commuter was overwhelmingly depicted as an individual on 13 caricatures out of 16 . If we look at the way how experts examined the individualfamily relationship, we can see that the representatives of the disciplines that placed commuting in the focus of the examination - demography, statistics, urban planning, transportation science -, treated commuters as individuals.So did economists, among the representatives of disciplines focusing on commuters, who saw commuters mainly as workforce.

In contrast to the mentioned disciplines, the majority of psychologists, criminologists and sociologists, drawn by different aspects of motivation, but designated family to be in the focus. György Konrád and Iván Szelényiwere the first sociologists to state why it was important to focus on families while doing the researches. "The fact, that almost one tenth of the society in Hungary commutes does not shadow the other fact that emerges: the contradiction of the town workplace and the village home indirectly affects other members of the family as well, and approximately a quarter of the Hungarian population bears the disadvantages arising from it." (Konrád - Szelényi 1971: 34) Konrád and Szelényi's realization is well illustrated in the caricature No14, whichs the latest among the drawings depicting commuters with their families, published in 1971; the caricature portrays the commuter and the family suffering from commuting simultaneously. In the drawing the man is portrayed as a pendulum that is swinging to and fro literally as a commuter; or according to another possible interpretation, he is oscillating between his family and the pub.

The other two caricatures out of the three focusing on family (Pictures No1 and No8) were published earlier, during the time of the collective farm organizational period (1958-1961). In my opinion, these drawing deliberately depict commuters in home environment in the village.

In order to understand these caricatures pointing out the rural characteristics of this period is vital. During this time thousands of village families felt that they were losing the work of their lives, their lands. There was chaos in the villages. Nobody knew for sure if the newly founded farmers' co-operatives would be dissolved in one or two years - as it happened before many times -, 


\section{THEMATIC PAPERS - Worker - life - representation}

or if they would not dissolve, how people would be able to leave them, how people would farm the land together. It was also unclear what kind of social changes and power struggles would the ownership shifts would bring to the villages. Town work and its correspondent commuting seemed to be the escape route from the chaotic village atmosphere. It is not a wonder that a significant number of the commuters in the decade, $89 \%$ of the people were the ones who commuted from villages to towns (Hungarian Census Of Population, 1970, "Központi Statisztikai Hivatal, 1970. évi népszámlálás").

Due to the industrial investments in the 50's factories saw a lack of work labour, and there was a huge demand for workers. Predictable working time and fix wages were incredibly tempting for the villagers. Having only one person from a family join the collective farm, and letting others, usually the younger ones try to look for a job elsewhere seemed to be a rational decision. They, $1 / 3$ of the active earners, youngsters between the age of 14 and 29 , made up $45 \%$ of the commuting active earners. During this time, in the 1960's, there were a relatively significant labour reserves of women, and as a consequence, between 1960 and 1970 the number of active working women grew by 364000 . Although the number of daily commuters among men in the 1960's increased more significantly $(190000)$ than the number of women (151 000), when looking at the rates, we can see a more dynamic increase among women $(127 \%)$ than among men $(37 \%)$ (Hungarian Census Of Population, 1970).

Village commutershad never been present in the Hungarian society in such big numbers and rates and more importantly in so highly motivated. This period was also special, as numerous villagers who had never thought about leaving their village borders before thanks to their stable financial situation, traditions and family connections were in need to do industrial works.

I think that the mentioned caricatures, which illustrate commuters in a home environment, depicted commuters with their families in a home environment as show where they truly belong to after the previously mentioned economic and social changes. When looking at all the caricatures included in the analysis, we can say, that out of the 16 drawings only these two were the ones that showed rural locations and the homes of the commuters. The majority of the drawings - eight illustrations -, showed commuters on different means of transportation (Pictures No2, No3, No4, No9, No10, No11, No13, No14, and No16), two in railway restaurants (Pictures No12, No15) and three at workers' hotels (Pictures No5, No6, No7).

These rates coincide with the interests of other forms of media. The locations of most articles, pictures and films were railway wagons and/or the railway. Commuters might have been illustrated at workers' hostels, and in the towns, but in home environmentless and less frequently as time went by. The only exception was Peter Korniss' photo album, The guest worker ("A vendégmunkás"), as he showed 


\section{THEMATIC PAPERS - Worker - life - representation}

his commuting subjects in rural environment as well. Péter Korniss photographer recorded the life of a commuting man, just like the majority of film producers, who portrayed mostly commuting men, as well. The question now arises: Was "Ludas Matyi" following the trend of other forms of media, and depicted predominantly men? Moreover, what do statistics say about the ratio of men and women commuters and their age breakdown? Did caricatures reflect the real ratio suggested by the statistics?

We may see the age structure first. Caricatures did not take a clear position on this issue. According to the statistics, the younger generation tried to lead a commuting life; this was the major labour problem for the collective farms in the $60 \mathrm{~s}$, as mostly older family members joined the collective farms. In the observed period, all through 1960 and $1980,45 \%$ and $41 \%$ of commuters were young people (aged between 14 and 29).

In the visual world, created exclusively by men, women were not really included; they were illustrated in only two pictures (Pictures No10 and No13). None of the disciplines engaged with commuting or commuters devoted special attention to examine the gender composition of the commuters, despite the fact that the number and the ratio of commuting women increased nationwide in the period. In 1960, every sixth active earnerman and every fifteenth woman worked away from their home place. In 1970, every fourth active earner man and every eighth active earner woman was a commuter. Despite the fact that half of the number increase of 241000 commuters between 1970 and 1980 were women, the ratio of the women among the commuters and among the active earners increased moderately.

For all these reasons, it is worth reflecting on why "LudasMatyi", in line with the other forms of visual and audio visual media, illustrated almost exclusively men commuters. My hypotheses is that the drawers wanted to depict long-distance commuters ${ }^{1}$ - among whom as opposed to the daily commuters - women were in a negligible proportion indeed. In order to examine the hypothesis, we have to look at the rate of the drawings about the daily and the long- distance commuters.

Six satires (Pictures No2, No3, No4, No5, No6 and No7) can be said to be illustrating specifically long-distance commuters. This can be stated with complete certainty as the locations of the drawings were either the workers' hostel or the workers' train. Four drawings definitely illustrate daily commuters (Pictures No1, No8, No12 and No13). The sign in picture No13 reveals that the bus was a short distance bus, the text in picture No12 clearly tells that the commuter travelled home daily, and pictures No1 and No8 reveal that the commuters portrayed in home environment commuted daily to their workplaces. The type of commuters

${ }^{1}$ The drawers, editors and the majority of the subscribers of "Ludas" lived in Budapest that is the reason why here; in the neighbourhood of the railway stations could they meet the most - quite evidently right from the first sight - non-urban workers. 


\section{THEMATIC PAPERS - Worker - life - representation}

represented in the six remaining pictures, however, cannot be determined with certainty.

Thus, we cannot state that the drawings solely illustrated long-distance commuters; the reason of ignoring women commuters - within the framework of this study - will remain unanswered unfortunately.

The question arises however, whether the rough $50-50 \%$ representation of longdistance and daily commuters in the caricatures correlates with the statistical data. The short answer is: no. And to be more explicit, we can say, that the so-called longdistance commuters, who travelled weekly, monthly or even less frequently home from a longer distance accounted for a very small proportion of all commuters (Hungarian Census Of Population, 1970).

The first survey covering all the industries nationwide on the number of commuters was conducted in 1960; this time the number of commuters was 636000 , every eighth active earner was regarded as a commuter. The number of the commuters and its rate among the active workers was continuously increasing: in 1970 there were 977000 commuters, every fifth active earner, and in 1980 their number reached 1218 000, every fourth active earner was commuting daily. During the observed two decades the number of daily commuters almost doubled, and during the same period of time the number of active earners grew by slightly more than 6\%. (Hungarian Census Of Population, 1980).

During the state socialism there were no regular statistics on the number of the long-distance commuters, the censuses in 1970 and 1980 comprise exclusively the so-called "number of long-term commuters", in 1970320220 persons, in 1980 270818 persons, among whom 70000 persons were daily-travellers as well, so neither their permanent, nor their temporarily place of living was the same as the place of their workplace. They were not the commuters whose number reached almost 2 million by the end of the era. They were women and men who after finishing their daily shifts rushed home 10 to $30 \mathrm{~km}$ away from the factory (by bus or by bicycle). They, the daily commuters and their problems were rarely shown by the media at that time.

Thus, the daily commuters, who were present in a large number and proportion based on the statistics, were underrepresented in the caricatures, as well as in the other forms of media. Representatives of disciplines as demography, statistics, ${ }^{2}$ geography, ${ }^{3}$ urban planning, ${ }^{4}$ transportation science ${ }^{5}$ however, were exclusively dealing with daily commuters.They mainly thought of daily commuters, who were commuting for work, but there were cases when they extended the term to

\footnotetext{
${ }^{2}$ See: Szabady (szerk.) 1964; Acsádi 1964; Orlicsek 1960.

${ }^{3}$ See: Beluszky 1961; Vörösmartiné 1971; Sárfalvi 1965, Lettrich 1975.

${ }^{4}$ See: Gerle 1974; Deák 1965; Perczel 1974; Preisich 1972.

${ }^{5}$ See: Bárány - Pápai 1964; Palotás 1965
} 


\section{THEMATIC PAPERS - Worker - life - representation}

students as well. While criminology ${ }^{6}$ examined only the long-distance commuters, economists, ${ }^{7}$ sociologists, ${ }^{8}$ and psychologists ${ }^{9}$ researched the lives of daily and longdistance commuters as well.

Even though commuters were at the forefront of more disciplines, none of them dealt with the external characteristics of the commuters. Caricatures however, offer excellent analytical field to observe such external properties as clothing, hairstyle and physique. In picture No1, which was created during the repeatedly mentioned collective farm organizational period, the characteristics of the commuting man followed the trends of the kulak depiction: a pot-bellied man with moustache wearing a short jacket ("mándli") and a pair of boots. ${ }^{10}$

However, from the end of the 60s and the beginning of the 70s, the boots and the "mándli" disappeared from the illustrations, and commuters were gradually illustrated with a luggage in their hands in the first time, and later on with a briefcase - as to refer to long- distance commuting. As time passed, commuters were more and more portrayed wearing urban working attire (Pictures No12, No13, No14 and No15). By the 80's the commuter was personified by figures reminiscent of lumpen elements: having long hair and stubble, wearing jeans/ trapeze pants, with a knife in his hands (Picture No7).

It can be seen that while illustrating the commuters in the caricatures, rural characteristics were less and less defining, as the urban, worker traits were getting more and more dominant. Several researches ${ }^{11}$ revealed that over the time wearing urban, modern clothes were getting more and more common in the villages as well, and the differences in the fashion trends were progressively decreasing. In the pictures of the analysed period, commuters were gradually getting younger: while commuters were rather personified by the age group of fifty in the 60 s, they were mostly manifested by people in their twenties in the 80s. The commuters' statistical breakdown by age has been mentioned above. ${ }^{12}$

It should also be noted, however, that during the collective farm organisational period, when commuters were depicted as kulaks, the worst inner enemies of the party were the farmers rejecting to join the collective farms, and they were portrayed as kulaks as well. And in the 80 s, one of the inner enemies of the party was the rebellious youth, following the western trends. Thus, when describing the caricature commuters, we can say, that even though the representation was constantly changing,

\footnotetext{
${ }^{6}$ See: 11 . footnote.

${ }^{7}$ See: 9 . footnote.

${ }^{8}$ See: 12 . footnote.

${ }^{9}$ See: 10 . footnote.

${ }^{10}$ The changes of the concept of kulak see: Bolgár 2008: 50-93.

${ }^{11}$ See: Valuch 2004.

12 See: Graph2.
} 


\section{THEMATIC PAPERS - Worker - life - representation}

one thing was constant: the drawings always portrayed features of figures that were the current internal enemies of the party.

Though there have been no publications about the external features mentioned so far, commuters' internal characteristics and emotions have often been the topic in scientific papers and in the media. Following the classification of the catalysis model mentioned before I will summarize the emotions commuters were endowed with in the following lines.

Themajority of the drawingsreflect the feelings of the boredom emotional group: mainly indifference, listlessness, lack of interest, gloominess and apathy. 1) The commuter for example, did not care about where to work, what to do that given day (Picture No1). There was a caricature, where apathy was not a characteristic of the commuter themselves, but of the other member or members of the family working in the collective farm (Picture No8).

The characterisation of commuters this time was influenced by the speech of Mátyá Rákosi at the at the National Miners' Meeting in 1951. Rákosi described commuters as follows: commuters demoralize the work, they are the ones who are more often absent from work because of sick- leave, have a hectic lifestyle, are exhausted, less precise at work, did not take an active part in social programmes, they are unable to learn or evolve, they are harmful to the society. ${ }^{13}$ The blindfolded commuter in picture No1 carries several features of what Rákosi mentioned: they demoralized work by arriving at work late (Picture No8), they led a hectic lifestyle (Picture No8), and they had an adverse effect on work organization and on the society as well, as they randomly decided on what to do that given day (Picture No1).

2) The commuter's family is uninterested in the work in the collective farms too (Picture No8), as it is shown in a picture that was published in 1960, during the time of collective farm organisation. To interpret this drawing, we should know that in the first years of the collective farms there were not only work labour problems, but problems with work disciplinary as well, due to the low motivation of the home labour, the unpredictability of wages and benefits and the messy circumstances. ${ }^{14}$ Work discipline problems were more intense at families, where there were commuters in the family, as they were financially less dependent on the collective farms.

3) As we can see in more caricatures (Pictures No3, No9 and No13), the commuter is indifferent to the travelling conditions as well: he tolerates travelling on crowded, unheated lines. Marching commuters in a line one by one like snowmen apathetically acknowledge the dreadful travelling conditions (Picture No3). I have written about the travelling conditions before, but not about the commuters' attitude. This is a

\footnotetext{
${ }^{13}$ Rákosi 1951.

${ }^{14}$ See: Varga 2009: 1-27.
} 


\section{THEMATIC PAPERS - Worker - life - representation}

topic that psychologists, criminologists and more commonly sociologists dealt with, and was mainly shown by the sociography. ${ }^{15}$ The majority of experts share the view with Mrs Aladár Mód, who briefly stated that: "There are still a lot of dirty, unclean wagons or buses. A lot of people travel standing up, and there is often no heating. The illegal sale of alcoholic drinks is still in practice and as a consequence, drinking and obscene talk is present. Travel conditions of commuters are improving very slowly, as these complaints were known 20 years ago as well. (...) Commuting workers have accepted these conditions for 20 years and it might be comfortable: it has not forced a thorough change. But comfort costs a lot of money to the society: having no standards is undemanding in other areas as well, those who passively tolerate the given bad circumstances are obviously even more passive in the public affairs." (Mód 1978: 74) Hence, experts recognized that bad travelling circumstances were not caused by the commuters themselves, and furthermore, they admitted that these circumstances negatively influence the travelling attitude of the commuters. The articles in the media were less objective; they took sides with the ones who stated that it is the commuters that are responsible for their bad conditions.

Some emotions that belong to the anger group often appeared in the caricatures too: commuters were equally angry, dissatisfied, violent, nervous, irritated, rebellious and bullying. This emotion was also related primarily to the travelling conditions. There was a caricature (Picture No2), which contrary to the aforesaid, presented commuters being dissatisfied with the conditions while travelling (mainly with the slowness). Many drawings were published that exposed commuters being violent (Pictures No6 and No7). Commuters are people in these drawings who break the socialist norms: they are drinking, and as a result of being intoxicated, are irresponsible (Pictures No6, No11, No12 and No15).

Scientific analysis usually did not separate crime and alcoholism; both features were attributed to deviant behaviour. László Berettyán after analysing the total labour force balance of the National Planning Office ("Országos Tervhivatal"), was among the firsts to come to a conclusion, that: "The situation of spending a long time travelling, and being far away from home, can lead to adverse consequences in many other respects, e.g. loosening of family ties, alcoholism, etc." (Berettyán 1965: 46) In later years, most authors from different disciplines attributed deviant behaviour only and exclusively to the lifestyles of long-distance commuters. ${ }^{16}$ I would quote only from József Gödöny, director of the National Institute of Criminology, who stated in his monograph "The socio-economic development and crime", in 1976,

\footnotetext{
${ }^{15}$ See: 21-28. footnotes and Erdei 1971; Csák 1977; Mesterházi 1974; Berkovits 1976.

${ }^{16}$ Venyige, Józsa Gyetvai authorsstated in 1975 that: „At this type of commuting (long-distance commuting) such undesired effects as alcoholism, crime, etc. are particularly common." (VenyigeJózsa-Gyetvai 1975:8) In Sándor Tar'swriting "Person 6714", published in 1981, the author discloses conversations about commuters as reports, that presented commuters at the same time vulnerable and deviant behaviour workers.Taar1981.
} 


\section{THEMATIC PAPERS - Worker - life - representation}

that: "A single father is exposed to dangers (misuse of free time, alcoholism, etc.) that lead to crime. This phenomenon is even more relevant in the case of juvenile or a young adult (male or female) migration in the family. The urban setting, the lack of sufficient life experiment creates a favourable soil for the impacts that lead to crimes. Prostitution for girls for example, vandalism, physical abuse, thefts, and gang activities for boys are the most common features." (Gödöny 1976: 201-202) Gödöny's writing is unique, as he scientifically told problems that had only been broadcast by different forms of media, giving the cause-and-effect relationship as well. In 1985, Antal Bőhm and László Pál stated in their publication Commuters of our society - the society of commuters ("Társadalmunk ingázói - az ingázók társadalma") that there were deviant individuals (alcoholism, criminology) in a higher proportions among commuters.

Emotions that belong to the fatigue group such as sleep deprivation, exhaustion, depression, grouchiness, and stressful life very often appeared in the caricatures. The marching commuters in a line one by one like snowmen seemed to be exhausted (Picture No3), commuters trying hard to get on the bus were grouchy (Picture No14), and the commuters travelling slowly on the bad roads are also dejected (Picture No13). As I mentioned earlier, Rákosi was among the firsts who stated that fatigue is specific to commuters and in this context less precise work. Commuters very often appear as forever tired people in films, photos, newspaper articles and in scientific papers.

When depicting fatigue some creators highlighted the commuters' commitment to working in the factory ${ }^{17}$ whereas others put more emphasize on the commuters' problems at the workplace. Of the latter, Ferenc Nemes and Tamás Rozgonyi coauthors were more nuanced regarding the work of commuters: "In the case of commuters)the time spent on idlerest increasesandprofessional training is almost impossible.[...] Commuting is physically demanding for the workers, so they arrive at their workplaces tired and it affects their mood at work to some extent." (NemesRozgonyi 1968: 29.) But most people associated commuters' exhaustion more with deviant behavioural forms similarly to Miklós Szántó and György Fukász: „Dead tired people, who are onlyshaken up when drinking or playing cards, and at best, they are fans in the matches." (Szántó - Fukász 1964: 126)

As regard to depicting fatigue, it is worth mentioning that a significant number of newspaper articles and studies blamed the commuters for their exhaustion. In most cases they also took over the logic of Rákosi speech on "kétlaki". According to the

${ }^{17}$ Authorsusually refer to the fact that commuters put up with double or triple as much burden as workers living in the towns, as they spend hours travelling before and after the shift, away from their families, in harsh conditions renting a bed or a flat, or living at a workers' hostel. 


\section{THEMATIC PAPERS - Worker - life - representation}

argument commuters are tired as material gain is too important for them, they want to profit from the production in the collective farms and home farming as well. ${ }^{18}$

Emotions that belong to the confusion group such as uncertainty, being lost, frustration, helplessness and confusion appear, together with other emotions, as kind of "sub emotions" besides the listed main emotion groups. The blindfolded work choice mentioned in the $1^{\text {st }}$ picture can reflect helplessness.But the life situation of people that are defenceless to the travelling conditions can be interpreted as being defenceless; even though it is not the main feeling their depiction reflects (Pictures No3, No13, and No14).

The same can be said about the emotions belonging to the sadness group as well. In the $13^{\text {th }}$ picture commuters besides being indifferent with regard to the road conditions are also moody, melancholic. Commuters in the $14^{\text {th }}$ picture are also not only angry but also careworn. Emotions that belong to the group of fear such as distrust, aloofness, suspiciousness, and dread appeared less frequently than the emotions mentioned earlier. Perhaps only the commuter in the $9^{\text {th }}$ picture can be said with certainty to be distrustful of his colleagues and fellow passengers.

Among the emotions of the seven main emotion groups feelings belonging to the emptiness group as for example hopelessness, shame and emptiness are the feelings that do not appear directly in the drawings. It cannot be said however, that these feelings were far from the commuters to be portrayed. Since, from other resources (sociography, films) we know the emptiness that characterize the life of commuters get drunk in the railway restaurants as in pictures No 12 and 15 well. The hopeless life of commuters entailed that commuters rather chose the pubs and buddies over their families as it was shown for example in the documentary Black Train, "Fekete vonat".

\section{Summary}

Summarizing the answers to the questions listed in the introduction, we can state that the drawings of caricaturists on commuters shared some characteristics, even though the pictures did not show a homogenous commuter figure. Compiling the above mentioned findings, it can be stated, that the commuter of "Ludas Matyi" was generally an ageless man who did not return to his family daily, but less frequently, and he spent most of his time with his commuting co-workers. Over the years the commuter of "Ludas Matyi" increasingly followed the urban trends both in his attire and his hairstyle. As for the personality of the commuter, it can be said, that he was usually unconcerned about his travelling circumstances and his factory work, his

\footnotetext{
${ }^{18}$ See more aboutthis: Varga 2012b: 93-107.
} 


\section{THEMATIC PAPERS - Worker - life - representation}

indifference had a bad influence on the work of his family members as well. The commuter, who rarely met his family, tended to have a deviant attitude, to be aggressive and an alcoholic as well.

The image of the commuter in "Ludas Matyi" mainly resembled to the commuter image of other media - films, photos, articles -, where commuters were seen as the "black train" community, and the commuter description caricatured the life of the long-distance commuters. Above, we could see what "Ludas Matyi" showed about the long-distance commuters, but for the comparison we have to mention the traits that other forms of media showed about the commuters.

Films and articles often described attributes of the "black train community", such as infidelity, conflicts between commuters and the urban co-workers, being inactive in programmes after work, alienation from the village and from agricultural work, integration problems in the factory for the commuters, which caricatures did not cover. In the counties - e.g. in Vas County-, where the number of commuters was high, besides the mentioned articles, the press often reported about the problems of the women who commuted by bicycle or on foot daily or weekly, and about the deplorable conditions of the bed rents. Thus, as we can say, that the caricatures of "Ludas Matyi" did not present commuting or commuters' properties that were not covered in other forms of media; they did not cover commuters or commuting topics that other media forms did.

Closing the analysis, I think it is worthwhile to attempt to answer to the rather complex questionn, as to how well the real anomalies of commuting at the time were reflected in "Ludas Matyi." The question should definitely be divided in two: the case of daily and long-distance commuters. The main initial problem of the daily commuters was to acquire the job in the town, and to ask for the working paper that was required for the job from the municipal council; for a villager, this was a huge problem. Commuting from a scarcely populated village that did not have a railway station also meant a huge problem; thousands of people living in these villages were forced to commute by bicycle or on foot. Placing the commuters' children in a kindergarten or day nursery encountered many obstacles. Doing the daily grocery often caused a problem because of the short opening times of the shops. Rural commuters felt excluded because of their habits, utterance and attire by townspeople. Double compliance meant an awful big burden for daily commuters: they had to fit into the village community and to the factory as well. Caricatures did not cover any of this non-exhaustive list of problems. Hence, in the case of daily commuters, we can say that caricatures did not reflect their real problems at all.

The same cannot be said in the case of long-distance commuters. Obviously, we cannot state that caricatures presented every little detail of the long-distance commuters' lives, but the travelling circumstances of long-distance commuters, the 


\section{THEMATIC PAPERS - Worker - life - representation}

difficulties of their family life, the miserable state of the workers' hostels, and their health-destroying behaviour (as of alcoholism) appeared in the caricatures. In my opinion, the statement cited above can be true to the analysed caricatures, as: "The real caricature (that grows in good weather conditions and if taken real care of) can depict the emblem of the day, the week or the era."(Kaján 1982: 97).

\section{References}

Acsádi, Gy. (1964): Vándorlás. In: Szabad Egon (szerk.): Bevezetés a demográfiába. Budapest, Közgazdaságiés Jogi Könyvkiadó, 393-460.

Andorka, R. (1979): A magyar községek társadalmának átalakulása. Budapest, Magvető Kiadó.

Anonymus (1971): A Népszabadság kerekasztala a Magyar humor hagyományairól és mai helyzetéről. Népszabadság 29: 1971. január 10: 5.

Bán, F. (1958): Csigalépcső. (film).

Bárány, L. - Pápai, B.(1964): A Budapest környéki ingavándorforgalom. Közlekedéstudományi Szemle 3: 97-106.

Bartha, E. (2016): „This Workers' Hostel Lost Almost Every Bit of Added Value it had": Workers' hostels, Social Rights and Legitimization in Welfare Dictatorships. In: Zimmermann, S. - Siefert, M. (eds.): Labor in State Socialist Europe after 1945: Contributions to Global Labor History. Budapest - New York, Central European University Press.

Beluszky, P. (1961): Berettyóújfalu vonzáskörzete. Acta Geographica Ac Geologica Et Meteorologica Debrecina 2: 239-264.

Berettyán, L. (1965): Magyarország területi munkaerőhelyzete (1961-1966 között). Munkaügyi Szemle 2-3: 42-48, 81-86.

Berkovits, Gy. (1976): Világváros határában. Budapest, Szépirodalmi Könyvkiadó.

Bolgár, D. (2008): A kulak érthető arca: Fogalomtörténeti vázlat. In: Horváth Sándor (szerk.): Mindennapok Rákosi és Kádár korában: Új utak a szocialista korszak kutatásában. Budapest, Nyitott könyvműhely, 50-93.

Bőhm, A. - Pál, L. (1985): Társadalmunk ingázói - az ingázók társadalma. Budapest, Kossuth Könyvkiadó.

Csák, Gy. (1977): A szikföld sóhaja. Budapest, Szépirodalmi Könyvkiadó.

Deák, S. (1965): A város környéki településeink helye a nagyvárosok fejlesztésében. Településtudományi Közlemények 17: 14-28.

Demeter, Zs. (1986): Karikatúrák a Ludas Matyiban. História 5-6: 19.

Erdei, F. (1971): Város és vidéke. Budapest, Szépirodalmi Kiadó. 


\section{THEMATIC PAPERS - Worker - life - representation}

Gaál, I. (1962): Oda-vissza. (film).

Gelléri, P. (1977): Vándorló munkások. Budapest, Akadémiai Kiadó.

Gerle,Gy.(1974): Környezet és településhálózat. Budapest, Akadémiai Kiadó.

Gödöny, J. (1976): A társadalmi-gazdasági fejlődés és bűnözés. Budapest, Közgazdasági és Jogi Könyvkiadó.

Gyöngy, K. (2008): Magyar karikaturisták adat- és szignótára 1848-2007. Budapest, Ábra KKT. és a kArton karikatúra és Képregény Múzeum Alapítvány.

Kaján, T. (1982): A karikaturista: alkalmazhatatlan grafikus. Jel-Kép 2: 97-99.

Kemény, I. (1972): A Magyar munkásosztály rétegződése. Szociológia 1: 36-48.

Konrád, Gy. - Szelényi, I. (1971): A késleltetett városfejlődés társadalmi konfliktusai. Valóság, 12: 19-35.

Központi Statisztikai Hivatal, 1970. évinépszámlálás 30. kötet, Aktív keresők munkahelye és lakóhelye. A napi ingázók adatai. 1977.; Hungarian Census Of Population, Volume No33, 1970 (1977).

Központi Statisztikai Hivatal, 1980. évi népszámlálás 33. Az aktív keresők munkahelye és lakóhelye. A naponta ingázók adatai. 1983.; Hungarian Census Of Population, Volume No30, 1980 (1983).

Kresalek, G. (1984): Humor és politikum: a Ludas Matyi 1948-as és 1953-as évfolyamainak elemzése. Budapest Főváros Levéltára közleményei 2: 265-291.

Lettrich, E. (1975): Településhálózat-urbanizáció-igazgatás. Jogtudományi közlöny 8: 486-488.

Losonczi, K. (1968): Az aktív keresők és az ingázás. Munkaügyi Szemle 1: 20-26.

Losonczi, K. (1973): A munkaerőmozgásról. Budapest, Kossuth Könyvkiadó.

Mesterházi, L. (1974): Viszontlátás. Budapest, Magvető Kiadó.

Mód, A. (1978): „Bejáró” életmód. Cél és valóság. Társadalmi Szemle 6: 67-76.

Nemes, F. - Rozgonyi, T. (1968): A munkahelyváltoztatás, mint munkaerőgazdálkodási probléma. Ergonómia 2: 5-35.

Orlicsek, J. (1960): A munka- és lakóhely közötti ingavándorforgalom adatainak figyelembevétele az ipar telepítésnél. Állam és igazgatás 10: 783-793.

Palásthy, Gy. (1968): Hazai pálya. (film).

Palotás, Z. (1965): Ingázás és munkaerő 1-3. Munkaügyi Szemle 10-12: 401-403; 433-437; 478-480.

Perczel, K. (1974): Faluhálózatunk jövője az urbanizálódás folyamatában. Területrendezés 1: 33-39. 


\section{THEMATIC PAPERS - Worker - life - representation}

Preisich, G. (1972): A budapesti település agglomerációtagolása, a központok rendszere. Területrendezés 3: 75-90.

Rákosi, M. (1951): Beszéd az Országos Bányászértekezleten, 1950. november 26-án. In: Rákosi, M.: A békéértés a szocializmusépítéséért. Budapest, Szikra Kiadó.

Sárfalvi, B. (1965): A mezőgazdasági népesség csökkenése Magyarországon. Budapest, Akadémiai Kiadó.

Schiffer, P. (1970): Fekete vonat (film).

Szabady, E. (1964): Bevezetés a demográfiába. Budapest, Közgazdaságiés Jogi Könyvkiadó.

Takács, R. (2003): Nevelni és felkelteni a gyűlöletet. A Ludas Matyi karikatúrái az 1950-es években. Médiakutató 4: 45-60.

Takács, R. (2006): Pesti humor a szocializmus idején: a karikatúra, a szatíra és a politikai kabaré szerepe. 20007-8: 90-105.

Tar, S. (1981): A 6714-es személy. Budapest, Magvető Kiadó.

Tóth, J. (2016): Kulaks in political cartoons of the Rákosi-era. In: Sorin, R. - Cosmin, B. (eds.): Countryside and Communism in Eastern Europe: Perceptions, Attitudes, Propaganda. LIT VERLAG GmbH \& Co. KG Wien, Zürich: 637-655.

Valuch, T. (2004): A lódentől a miniszoknyáig. Budapest, Corvina Kiadó.

Varga, Zs. (2009): „Földindulás után”. A hatalom és a parasztság Magyarországon az 1960-as évek első felében. Történelemi Szemle 2: 1-27.

Varga, Zs. (2012a): A fold szerepének változása a paraszti értékrendben a 20. század második felében. In: Dobszay, T. - Erdődy, G. - Manhercz, O. (szerk.): Milyen nemzetet, kinek, hogyan? Tanulmányok Magyarország történelméről 17801948. Budapest, Tálentum Kiadó, 243-252.

Varga, Zs. (2012b): „Fél lábbal a földön, fél lábbal az iparban... (A kétlakiakról szóló diskurzus főbb fordulópontjai az államszocializmus időszakában)” In: Bartha, E. - Varga, Zs. (szerk.): Határokon túl. Budapest, L’Harmattan, 93-107.

Varga, Zs. (2012c): „Mi történt a szovjetkolhoz-modellel Magyarországon? Egy adaptációs kísérlet vázlatos története" In: Majoros, I. (szerk.): Háborúk, békék, terroristák. Székely Gábor 70 éves. Budapest, ELTE, Új-és Jelenkori Egyetemes Történeti Tanszék, 627-640.

Venyige, J. - Józsa, Ö. - Gyetvai, L. (1975): Munkaerő-szerkezet és mobilitás. Budapest, Közgazdaságiés Jogi Könyvkiadó.

Vörösmartiné, E. (1971): A munkahely és a lakóhely közötti térbeli kapcsolat alakulásána tendenciái a budapesti agglomerációban. Földrajzi Értesítő 2: 131151. 
www. metszetek.unideb.hu

\section{THEMATIC PAPERS - Worker - life - representation}

W., Ames: Caricature and cartoon. https://www.britannica.com/art/caricature-andcartoon. Last download: 2019.01.09.

\section{Caricatures}

Brenner, Gy. (1983): Workers' hostel, “Munkásszállás”. In: Ludas Matyi 39, 19.05. 1983, 3.

Brenner, Gy. (1984): Workers' hostel, "Munkásszállás". In: Ludas Matyi 40, 10.05. 1984, 7.

Brenner, Gy. (1985): MÁV (Hungarian State Railways) is in trouble, "Gondban a MÁV." In: Ludas Matyi 41, 08.08.1985, 8.

Kaján, T. (1961): There are many "kétlaki” in Dudar, “Dudaron sok a kétlaki." In: Ludas Matyi 17, 07.09.1961, 10.

Kallus, L. (1968): At the workers' hostel, “Munkásszálláson.” In: Ludas Matyi 24, 23.05.1968, 12.

Lehoczki, I. (1980): Commuters, “Ingázók.” In: Ludas Matyi 36, 11.09.1980, 11.

Mészáros, A. (1968): Workers' train, “Munkásvonat.” In: Ludas Matyi 24, 30.01.1968, 11.

Nagy, T. (1979): Commuter, “Ingázó.” In: Ludas Matyi 35, 18.10.1979, 15.

Anonymous (1964): The workers' train has arrived, "Megérkezett a munkásvonat." In: Ludas Matyi 20, 30.01.1964, 12.

Piri, B. (1962): Neglected road, “Elhanyagolt út.” In: Ludas Matyi 18, 12.07.1962, 14.

Pusztai, P. (1960): Morning in the village, "Falusi reggel." In: Ludas Matyi 16, 27.10. 1960, 4.

Pusztai, P. (1968): Commuter, “Ingázók”. Ludas Matyi 24, 04.01.1968, 2.

Sajdik, F. (1968): Workers' train, “Munkásvonat”. In: LudasMatyi 24, 30.01.1968, 11.

Szepes, B. (1974): Commuter, “Ingázó”. In: Ludas Matyi 30, 14.02.1974, 1.

Takács, Z. (1969): At the "resti" (railway station pub), "Vasúti restiben." In: Ludas Matyi 25, 16.01, 3. 
www. metszetek.unideb.hu

\section{THEMATIC PAPERS - Worker - life - representation}

\section{SUPPLEMENT}

\section{Caricatures}

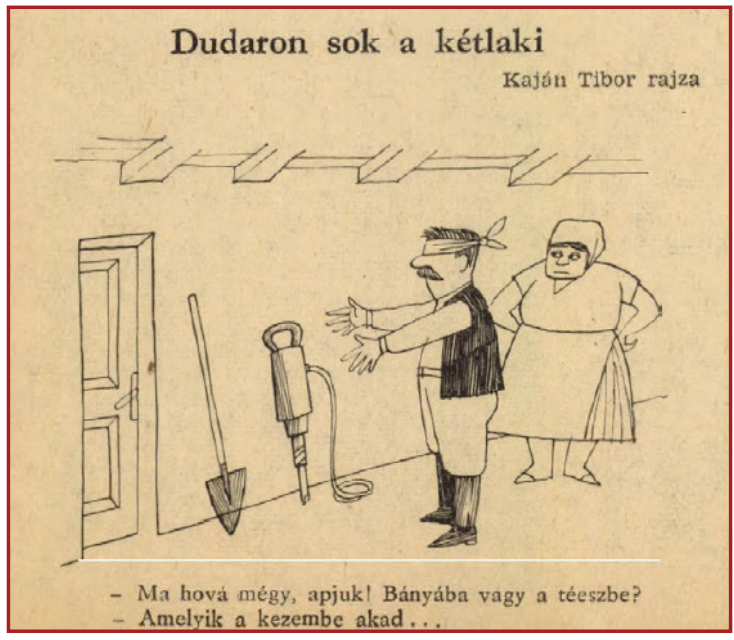

- Where are you going today, father? To the mine or to the collective farm?

- Which ever comes in my hand...

Picture No1. Kaján, T. (1961): There are many "kétlaki" in Dudar, "Dudaron sok a kétlaki." In: Ludas Matyi 17, 07.09.1961, 10.

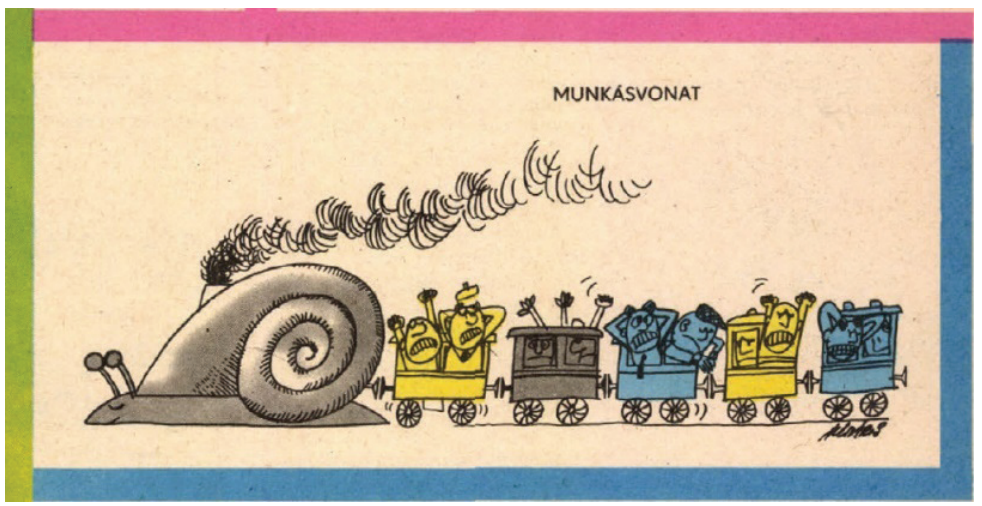

Picture No2. Mészáros, A. (1968): Workers' train, “Munkásvonat.” In: Ludas Matyi 24, 30.01.1968, 11. 
www. metszetek.unideb.hu

\section{THEMATIC PAPERS - Worker - life - representation}

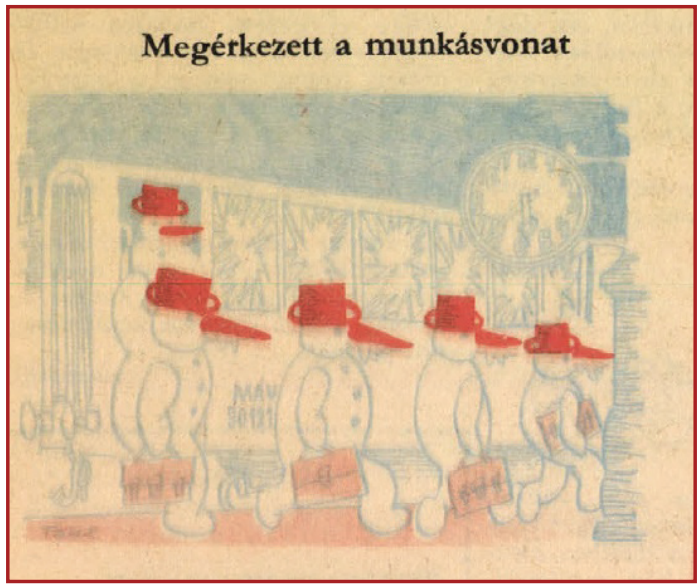

Picture No3. Anonymous, 1964: The workers' train has arrived, "Megérkezett a munkásvonat." In: Ludas Matyi 20, 30.01.1964, 12.

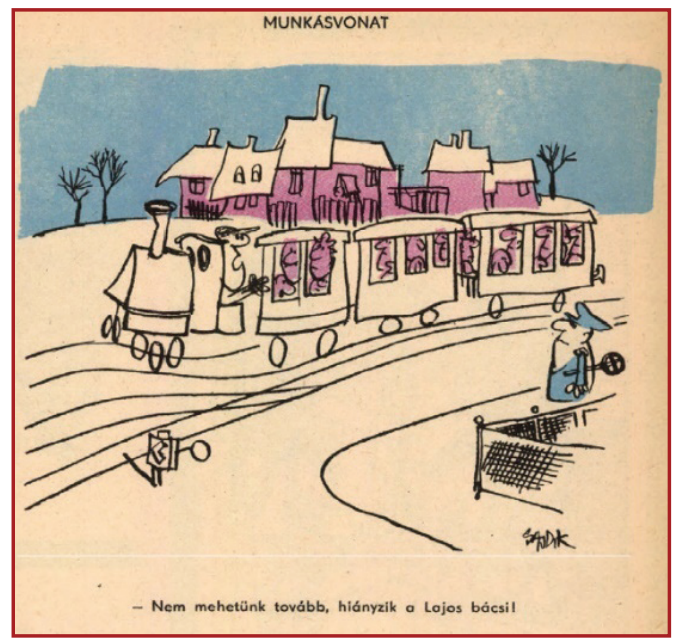

- We can't go on, Uncle Luis is missing!

Picture No4. Sajdik, F. (1968): Workers' train, "Munkásvonat". In: Ludas Matyi 24, 30.01.1968, 11. 


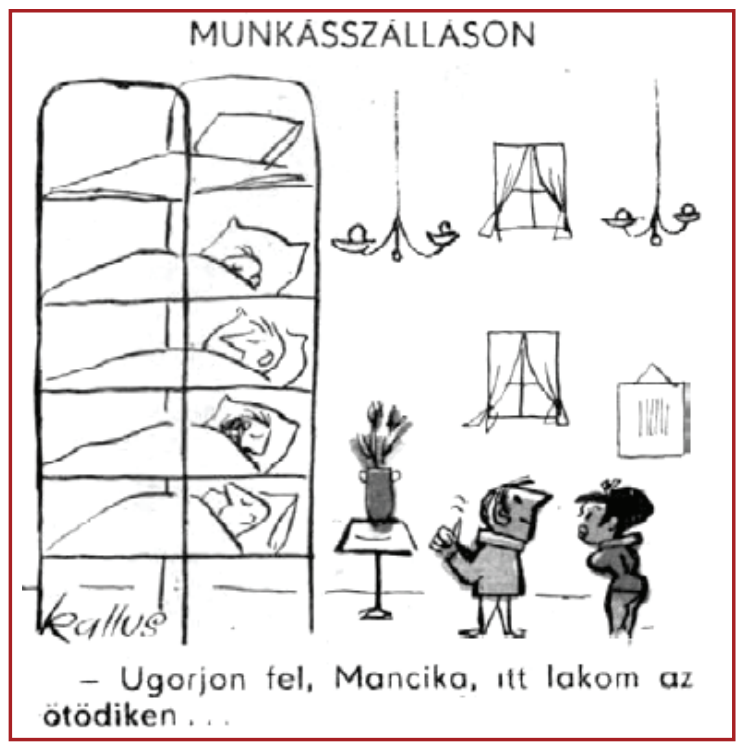

- Come over Mancika, I live here on the fifth...

Picture No5. Kallus, L. (1968): At the workers' hostel, “Munkásszálláson.” In: Ludas Matyi 24, 23.05.1968, 12.

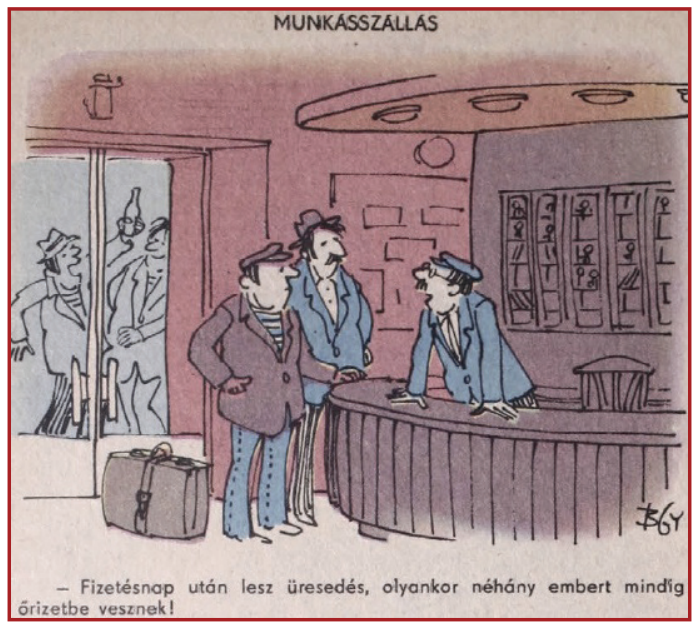

- There will be a vacancy after the payday, some people are always arrested that time!

Picture No6. Brenner, Gy. (1984): Workers' hostel, “Munkásszállás”. In: Ludas Matyi 40, 10.05.1984, 7 . 
www. metszetek.unideb.hu

\section{THEMATIC PAPERS - Worker - life - representation}

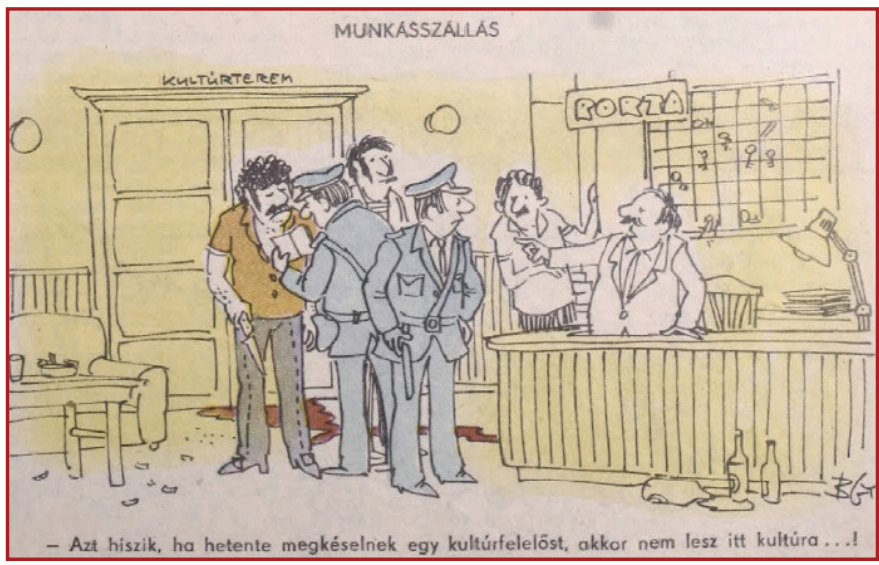

- They think that there will be no culture here if they weekly stab the person responsible for the culture...!

Picture No7. Brenner, Gy. (1983): Workers' hostel, “Munkásszállás”. In: Ludas Matyi 39, 19.05.1983, 3.

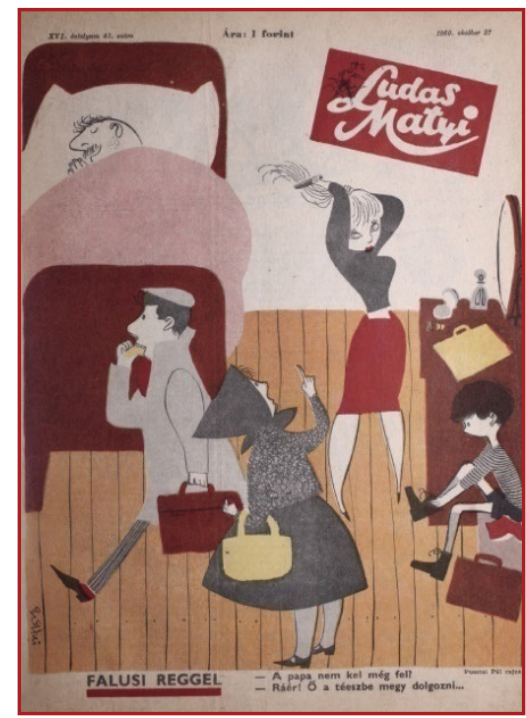

- Won't Daddy get up?

- He has time! He'll go working in the collective farm.

Picture No8. Pusztai, P. (1960): Morning in the village, "Falusi reggel." In: Ludas Matyi 16, 27.10.1960, 4. 
www. metszetek.unideb.hu

\section{THEMATIC PAPERS - Worker - life - representation}

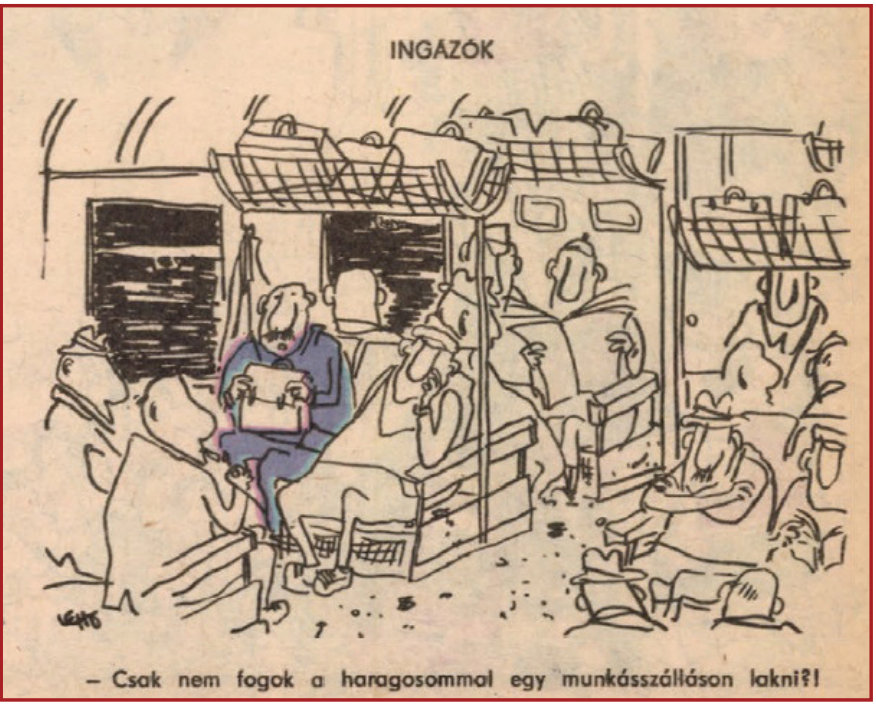

- I won't stay at the same workers' hostel as the person I'm angry with, will I?

Picture No9. Lehoczki, I. (1980): Commuters, “Ingázók.” In: Ludas Matyi 36, 11.09. 1980, 11.

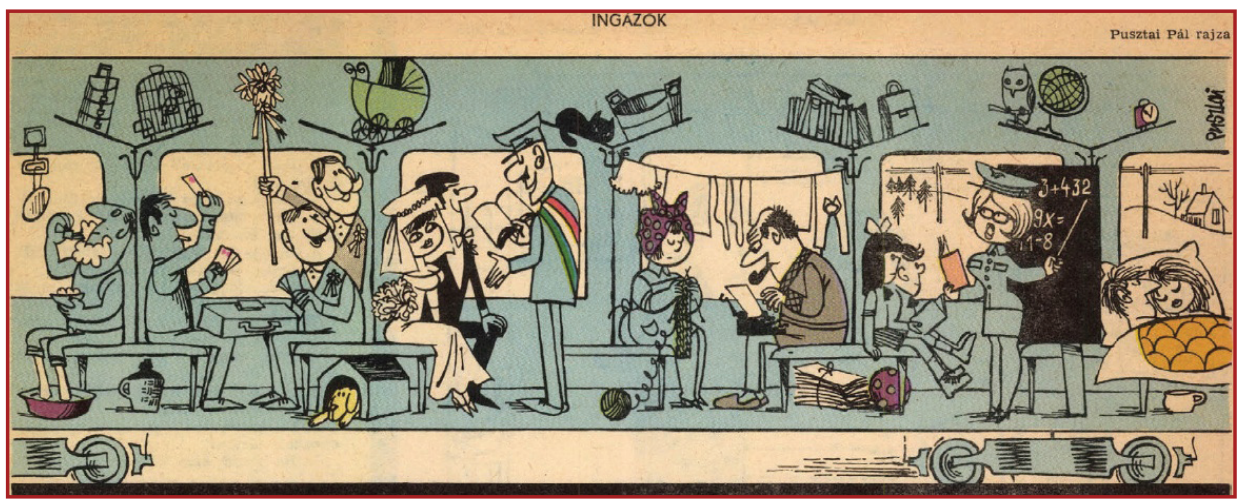

Picture No10. Pusztai, P. (1968): Commuters, "Ingázók". Ludas Matyi 24, 04.01. 1968, 2. 
www. metszetek.unideb.hu

\section{THEMATIC PAPERS - Worker - life - representation}

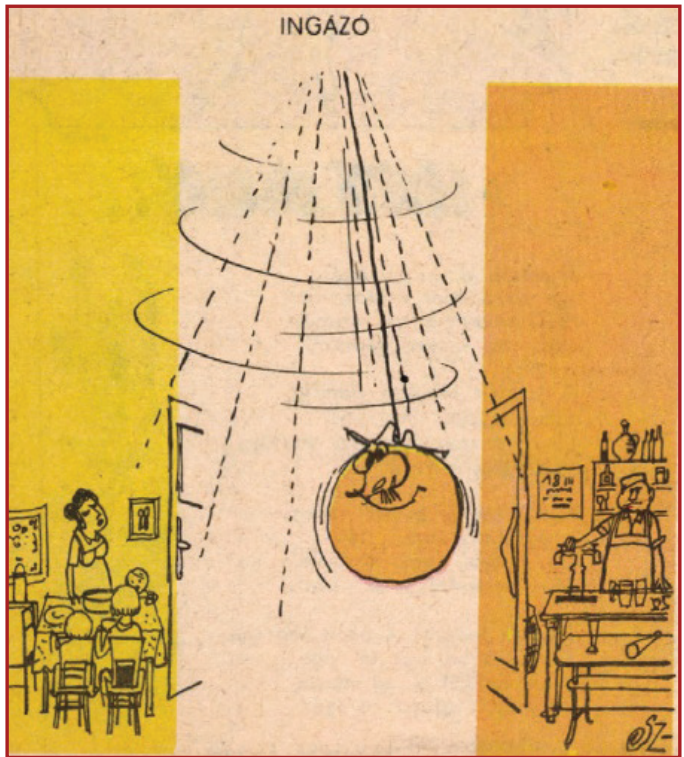

Picture No11. Szepes, B. (1974): Commuter, "Ingázó”. In: Ludas Matyi 30, 14.02. 1974, 1.

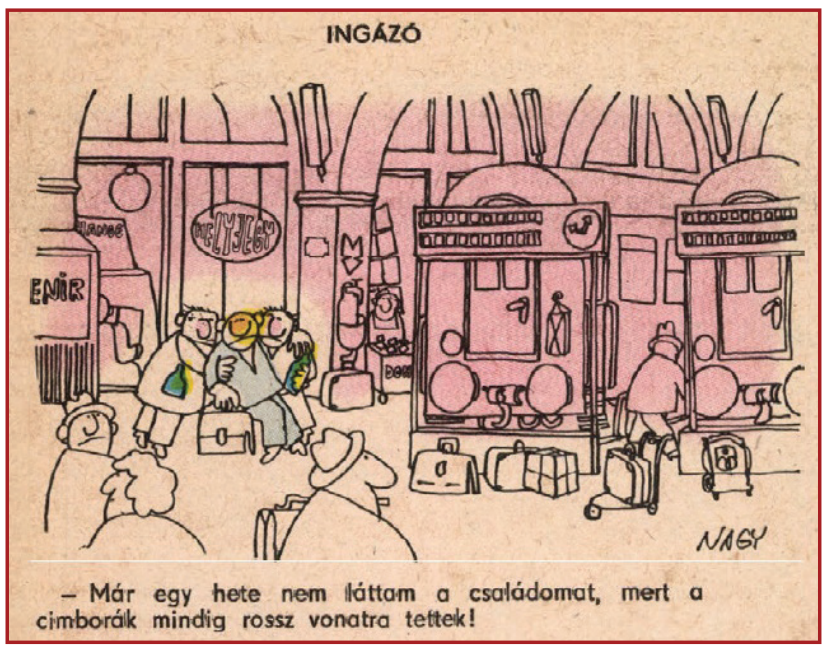

- I haven't seen my family for a week now, as my buddies always put me on the wrong train!

Picture No12. Nagy, T. (1979): Commuter, “Ingázó.” In: Ludas Matyi 35, 18.10. $1979,15$. 
www. metszetek.unideb.hu

\section{THEMATIC PAPERS - Worker - life - representation}

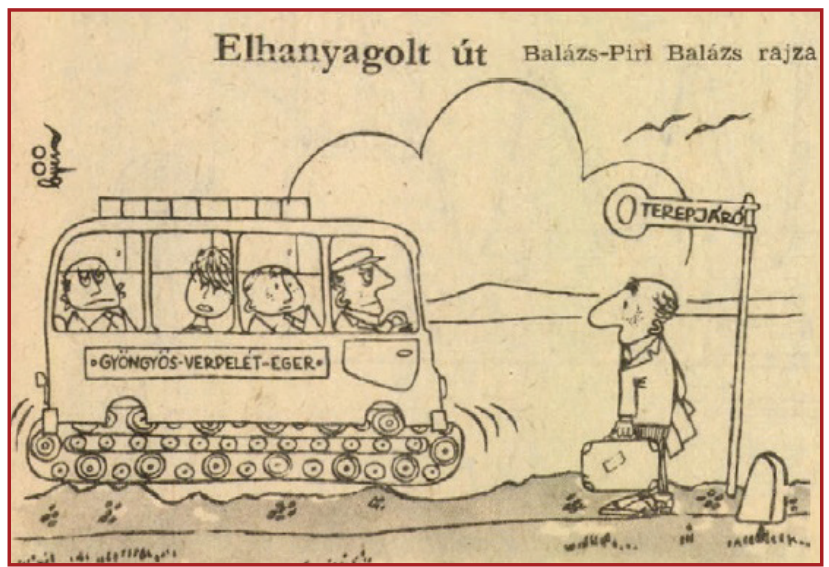

Picture No13. Piri, B. (1962): Neglected road, “Elhanyagolt út.” In: Ludas Matyi 18, 12.07.1962, 14 .

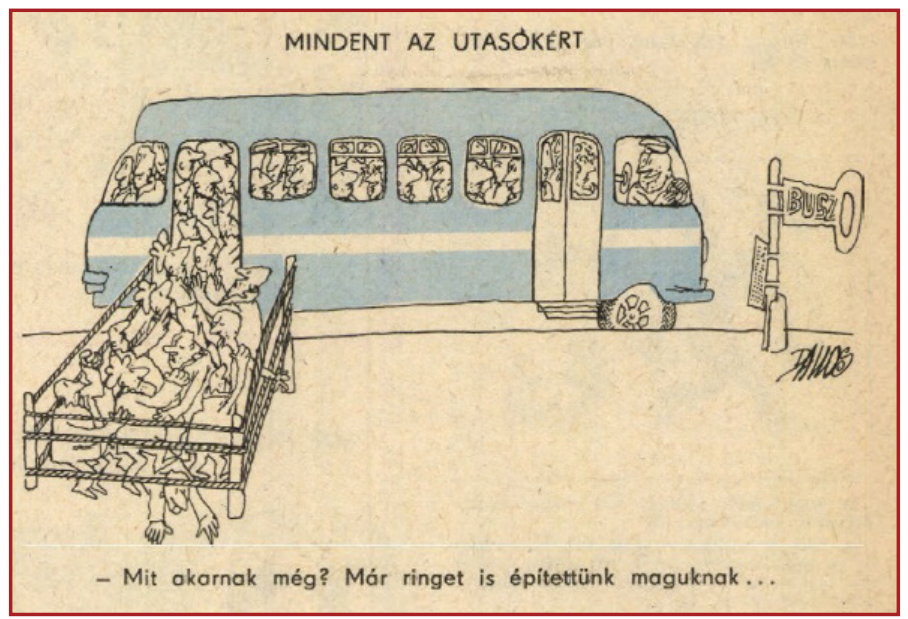

- What else do they want? We have already built a ring for ourselves...

Picture No14. Anonymus (1974): Everything for passengers! "Mindent az utasokért." In: Ludas Matyi 26, 14.02.1974, 2. 
www. metszetek.unideb.hu

\section{THEMATIC PAPERS - Worker - life - representation}

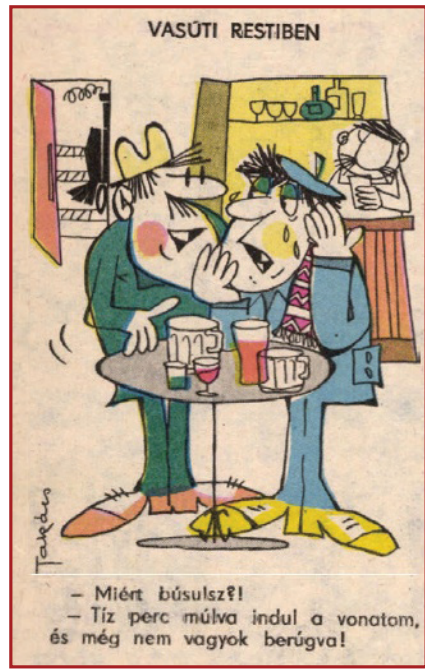

- Why are you so sad?

- My train leaves in ten minutes, and I'm still not drunk!

Picture No15. Takács, Z. (1969): At the "resti" (railway station pub), "Vasúti restiben." In: Ludas Matyi 25,16.01, 3.

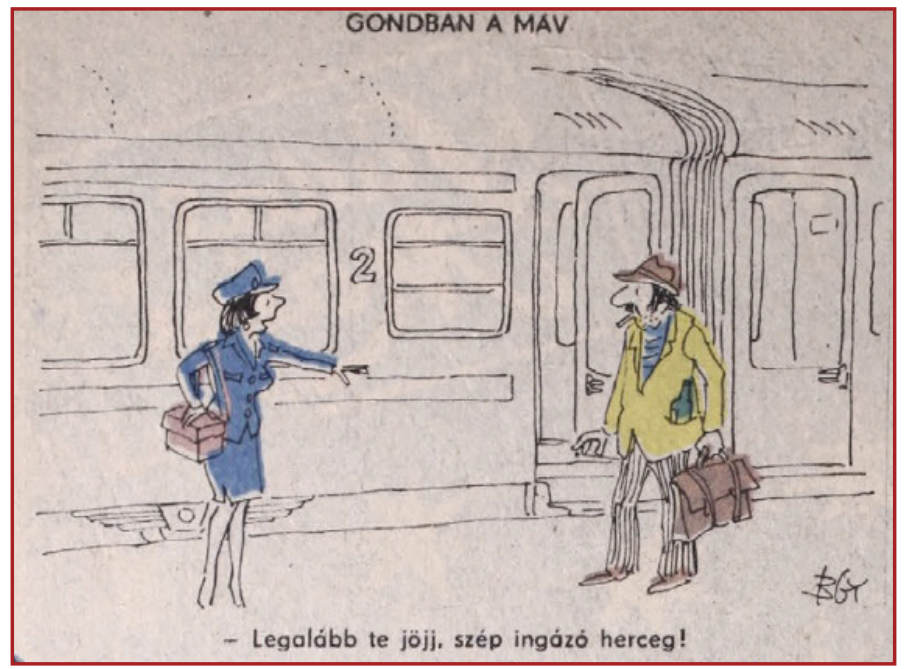

- At least you come, handsome commuting prince!

Picture No16. Brenner, Gy. (1985): MÁV (Hungarian State Railways) is in trouble, “Gondban a MÁV." In: Ludas Matyi 41, 08.08.1985, 8. 